\title{
Major-minor element analysis in some plant seeds consumed as feed in Turkey
}

\author{
Umran Hicsonmez ${ }^{1^{*}}$, Canan Ozdemir ${ }^{2}$, Sermin Cam $^{3}$, Ali Ozdemir ${ }^{4}$, F. Serap Erees ${ }^{3}$ \\ ${ }^{1}$ Department of Chemistry, Faculty of Sciences and Arts, Celal Bayar University, Manisa, Turkey; \\ *Corresponding Author: umran.hicsonmez@,cbu.edu.tr \\ ${ }^{2}$ Department of Biology, Faculty of Sciences and Arts, Celal Bayar University, Manisa, Turkey \\ ${ }^{3}$ Department of Physics, Faculty of Sciences and Arts, Celal Bayar University, Manisa, Turkey \\ ${ }^{4}$ Department of Mathematics, Faculty of Sciences and Arts, Celal Bayar University, Manisa, Turkey
}

Received 20 June 2011; revised 25 July 2011; accepted 10 August 2011

\begin{abstract}
In this study, samples (clover, oats, bean, green lentil, spinach, corn, red lentil and rice) taken from some seeds consumed as food by people and from plant seeds used as provender are examined. Element analysis (Al, B, Ba, Bi, Ca, $\mathrm{Cd}$, Co, Cr, Cu, Fe, K, La, Mg, Mn, Na, Ni, Pb, Sn, $\mathrm{Sr}, \mathrm{Sb}, \mathrm{Si}, \mathrm{Ti}, \mathrm{U}, \mathrm{Zn}$ and $\mathrm{Zr}$ ) in these samples was measured by using ICP-OES. $\mathrm{Ca}, \mathrm{K}$ and $\mathrm{Mg}$ as major elements in all samples are determined. As results of the element analysis, meaningful relations between the elements in seeds have been researched by making statistical comparisons using one way analysis of variance (ANOVA).
\end{abstract}

Keywords: Seed; Element Analysis; ICP-OES; ANOVA

\section{INTRODUCTION}

In the last few decades, the determination of minerals and trace elements is important to enhance production efficiency in plants and foods [1]. The various elements transfer to the food chain of humans is significantly affected by the geological origin of the soils and the groundwater basin as well as the living area of the flora and the drinking water reservoir. Some of the trace elements including iron, manganese, zinc and copper are essential micronutrients with a variety of biochemical functions in all living organisms. However, the benefits of these micronutrients may be completely reversed if present at high concentrations. Some heavy metals particularly cadmium and lead, not essential elements for human nutrition, on the other hand, have been considered serious soil and environment pollutant due to their potential toxicity at low concentrations [2]. In addition, uranium and potassium- 40 which is radioisotope of its ele- ment get into the flora and are comprehensively stored in young plants [3].

Recent studies have shown that some of the seeds could find application as animal feeds, based on their nutritional values, and raw materials for paint formulation based on the amounts and nature of the oils contained in them $[2,4-7]$. In the study made by Bakoglu et al., nine elements $(\mathrm{Cu}, \mathrm{Mn}, \mathrm{Cr}, \mathrm{Ni}, \mathrm{Zn}, \mathrm{Fe}, \mathrm{Mg}, \mathrm{Al}$ and $\mathrm{Pb})$ were detected and protein contents were determined between 18.40 - 45.54 percentages in the seed. According to $\mathrm{Ba}-$ koglu et al. M. minima var. minima's seeds are a good source of essential and beneficial micronutrients required for healthy growth [8]. Kranner and Colville (2011) had been investigated the transport of metals to developing seeds, the tissue-specific localization of metals within seeds, and finally the uptake of metals from soil by intact seeds [9].

Ajayi (2008) also found that the seeds were good sources of mineral elements. The result revealed potassium to be the prevalent mineral elements which are $2470.00 \mathrm{ppm}$ and $1680.00 \mathrm{ppm}$ for A. heterophyllus and T. africana, respectively followed by sodium, magnesium and then calcium [4].

The techniques most widely used for analyses of various plants include ICP-OES (Inductively coupled plasma optical emission spectrometry), ICP-AES, ICP-MS (Inductively coupled plasma mass spectrometry), FAAS (Flame atomic absorption spectrometry) and ETAAS (Electrothermal AAS) $[1,2,5,8,10]$.

ICP (Inductive coupled plasma) diffusion spectroscopy is commonly used as a good element analysis technique today and it has got the capacity to measure considerable amount of elements at same time.

Chaves et al. (2010) have proposed methods for the determination of 5 major $(\mathrm{Ca}, \mathrm{K}, \mathrm{Mg}, \mathrm{Na}$ and $\mathrm{P})$ and 14 minor elements (Al, Ba, $\mathrm{Cd}, \mathrm{Co}, \mathrm{Cu}, \mathrm{Fe}, \mathrm{Ga}, \mathrm{Mn}, \mathrm{Mo}, \mathrm{Ni}$, $\mathrm{Pb}, \mathrm{Rb}, \mathrm{Sr}$ and $\mathrm{Zn}$ ) in vegetable seeds by ICP OES and by ICP-MS, respectively. Among the four major studied elements, $\mathrm{K}$ was more concentrated, followed by $\mathrm{P}, \mathrm{Mg}$ 
and $\mathrm{Ca}$ for the majority of the seeds. Among the elements determined by ICP-MS, Fe, Zn, Na, Al and Mn showed higher concentrations [11].

In another study in England, Jung and Thornton (1997) made element analysis in soils, rice caulines and waters by using ICP-AES. They examined concentrations of element $\mathrm{Cd}, \mathrm{Cu}, \mathrm{Pb}, \mathrm{Zn}$ and $\mathrm{N}$ in rice and rice cauline. Results of $\mathrm{Cd}, \mathrm{Cu}, \mathrm{Pb}, \mathrm{Zn}$ and $\mathrm{N}$ concentrations in rice cauline varied as $0.20-0.70 \mu \mathrm{g} / \mathrm{g}, 5.3-22.6 \mu \mathrm{g} / \mathrm{g}, 3.1-$ $10.3 \mu \mathrm{g} / \mathrm{g}, 27-486 \mu \mathrm{g} / \mathrm{g}$ and $31 \mu \mathrm{g} / \mathrm{g}$, respectively. Also concentrations of $\mathrm{Cd}, \mathrm{Cu}, \mathrm{Pb}, \mathrm{Zn}$ and $\mathrm{N}$ in rice varied as $0.20-0.70 \mu \mathrm{g} / \mathrm{g}, 5.3-22.6 \mu \mathrm{g} / \mathrm{g}, 3.1-10.3 \mu \mathrm{g} / \mathrm{g}, 27$ - 486 $\mu \mathrm{g} / \mathrm{g}$ and $31 \mu \mathrm{g} / \mathrm{g}$, respectively [12].

In our study, element analysis of some seeds consumed as food by people and some plant seed used as provender was measured by using ICP-OES. As results of the element analysis, by making statically comparisons, meaningful relations between elements in seeds have been researched. Statistical analyses were performed using MINITAB software package [13].

\section{MATERIALS AND METHODS}

Seeds were bought from seed wholesalers and local markets in Western Turkey (Manisa, Izmir provinces or towns). Samples (clover, oats, bean, green lentil, spinach, corn, red lentil and rice) were grinded in a grinder.

One gram powdered dry samples were weighed into $100 \mathrm{ml}$ glass beakers. $3 \mathrm{~mL}$ of $65 \% \mathrm{HNO}_{3}$ and $5 \mathrm{~mL}$ of $35 \% \mathrm{H}_{2} \mathrm{O}_{2}$ was added to the samples and allowed to react overnight. The following morning the beakers were carefully heated until clear solutions were obtained. Care was taken to ensure that the samples did not dry. A mixture of $3 \mathrm{~mL} 65 \% \mathrm{HNO}_{3}$ and $9 \mathrm{~mL} 37 \% \mathrm{HCl}$ was added and gently heated until a small volume of acid remained. The residue was filtered and solutions were precisely transferred to $100 \mathrm{~mL}$ plastic standard flasks and made to volume with deionized water.

Element concentrations of $\mathrm{Al}, \mathrm{B}, \mathrm{Ba}, \mathrm{Bi}, \mathrm{Ca}, \mathrm{Cd}, \mathrm{Co}$, $\mathrm{Cr}, \mathrm{Cu}, \mathrm{Fe}, \mathrm{K}, \mathrm{La}, \mathrm{Mg}, \mathrm{Mn}, \mathrm{Na}, \mathrm{Ni}, \mathrm{Pb}, \mathrm{Sb}, \mathrm{Si}, \mathrm{Sn}, \mathrm{Sr}, \mathrm{Ti}$, $\mathrm{U}, \mathrm{Zr}$ and $\mathrm{Zn}$ were analyzed with a Perkin-Elmer 2001 Model Inductively Coupled Plasma-Optic Emission Spectrometry (ICP-OES).

The statistical results were made by using the one-way of ANOVA test. The differences were assessed by oneway ANOVA test. The reason for doing an ANOVA is to see if there is any difference between groups on some variable. One-way ANOVA is used to test for differences of among two or more groups. The significance at $\mathrm{P}<$ 0.05 and $\mathrm{P}<0.01$ levels has been considered for evaluation [13].

\section{RESULTS AND DISCUSSION}

Concentrations of element $\mathrm{Co}, \mathrm{Na}, \mathrm{Ca}, \mathrm{Mg}, \mathrm{Al}, \mathrm{B}, \mathrm{Ba}$,
$\mathrm{Cu}, \mathrm{Mn}, \mathrm{Ni}, \mathrm{Zn}, \mathrm{Cr}, \mathrm{Cd}, \mathrm{Sn}, \mathrm{K}, \mathrm{Ti}, \mathrm{Fe}, \mathrm{Sr}, \mathrm{Sb}, \mathrm{Si}, \mathrm{Pb}, \mathrm{Bi}$, $\mathrm{U}, \mathrm{La}$, and $\mathrm{Zr}$ of the clover, oats, bean, green lentil, spinach, corn, red lentil and rice samples are given Table 1 by using ICP-OES.

It is concluded from the results of element concentrations for the bean, green lentil, spinach, corn, red lentil and rice seeds consumed as food by humans with clover and oats used as provender for animals by using ICPOES. According to Table 1;

- In the element analysis made by using ICP-OES, element concentrations of $\mathrm{Cd}, \mathrm{Sb}$, and $\mathrm{La}$ have not been detected in all samples.

- It has been determined that element concentrations of $\mathrm{Co}, \mathrm{Na}, \mathrm{Ca}, \mathrm{Mg}, \mathrm{Al}, \mathrm{Cu}, \mathrm{Mn}, \mathrm{Zn}, \mathrm{Cr}, \mathrm{Sn}, \mathrm{K}, \mathrm{Ti}, \mathrm{Fe}, \mathrm{Sr}$, $\mathrm{Si}, \mathrm{Pb}$ and $\mathrm{Bi}$ were present in all samples. The element B was not detected in 3 plant seeds (spinach, corn and rice). It was measured maximum concentration in red lentil as $0.5 \mathrm{mg} / \mathrm{kg}$. Metal nutrients, such as iron $(\mathrm{Fe})$, manganese $(\mathrm{Mn})$, zinc $(\mathrm{Zn})$, and copper $(\mathrm{Cu})$, are essential for normal plant growth. During rice seed germination, the nutrients stored in the seed are used for germination. The rice seed is composed mainly of embryo and endosperm and the metal nutrients are stored in both structures [14].

- The element Ba was not detected in 3 samples (corn, red lentil and rice). It was measured maximum concentration in spinach as $4.8 \mathrm{mg} / \mathrm{kg}$.

- The element Ni was not detected in a rice sample. It was measured maximum concentration in oats as 3.7 $\mathrm{mg} / \mathrm{kg}$. Foods with mean nickel concentrations $>1$ $\mathrm{mg} / \mathrm{kg}$ included oatmeal, wheat bran, dried beans, soya products, soup powder, tea leaves, hazelnuts, peanuts, lucerne seeds, sunflower seeds, licorice, spices, cocoa, and dark chocolate [15].

- The element U was not detected in 2 samples (clover and corn). Uranium concentrations were measured as $\leq 1 \mathrm{mg} / \mathrm{kg}$ in other seeds. Anke et al. investigated the specific uranium contents of most of the116 foodstuffs. All sugar-, starch- and fat-rich foodstuffs like margarine, bee honey, pearl barley, semolina and vanilla blancmange, cereal grains, seeds, cocoa, coffee, flour, wheat and rye bread, rolls, etc. are generally poor in uranium (0.8 - $1.9 \mathrm{mg} / \mathrm{kg}$ dry matter) [3].

In the literature, the concentrations of element $\mathrm{Ca}, \mathrm{Cd}$, $\mathrm{Co}, \mathrm{Cu}, \mathrm{Fe}, \mathrm{K}, \mathrm{Mg}, \mathrm{Na}, \mathrm{Mn}, \mathrm{Ni}, \mathrm{Pb}$ and $\mathrm{Zn}$ in spinach were measured as $17144 \mathrm{mg} / \mathrm{kg}, 0.77 \mathrm{mg} / \mathrm{kg}, 1.41 \mathrm{mg} / \mathrm{kg}$, $2.71 \mathrm{mg} / \mathrm{kg}, 166.4 \mathrm{mg} / \mathrm{kg}, 3100 \mathrm{mg} / \mathrm{kg}, 2370 \mathrm{mg} / \mathrm{kg}$, $5460 \mathrm{mg} / \mathrm{kg}, 9.9 \mathrm{mg} / \mathrm{kg}, 17.14 \mathrm{mg} / \mathrm{kg}, 9.44 \mathrm{mg} / \mathrm{kg}$ and $9.6 \mathrm{mg} / \mathrm{kg}$, respectively by using atomic absorption spectrophotometer (AAS) in Egypt [16]. The concentrations of element $\mathrm{P}, \mathrm{Mn}, \mathrm{Fe}, \mathrm{Co}, \mathrm{Ni}, \mathrm{Cu}, \mathrm{Zn}, \mathrm{Se}$ and $\mathrm{Mo}$ in lentil were measured as $3380 \mu \mathrm{g} / \mathrm{g}, 14.3 \mu \mathrm{g} / \mathrm{g}, 81.5 \mu \mathrm{g} / \mathrm{g}, 0.071$ $\mu \mathrm{g} / \mathrm{g}, 1.89 \mu \mathrm{g} / \mathrm{g}, 8.52 \mu \mathrm{g} / \mathrm{g}, 42.1 \mu \mathrm{g} / \mathrm{g}, 1.03 \mu \mathrm{g} / \mathrm{g}$ and 12.7 $\mu \mathrm{g} / \mathrm{g}$, respectively, by using ICP-MS in Czechoslavakia 
Table 1. Element concentrations of the plant seeds as $\mathrm{mg} / \mathrm{kg}$ in dry matter.

\begin{tabular}{|c|c|c|c|c|c|c|c|c|}
\hline Element & Clover & Oats & Bean & Green lentil & Spinach & Corn & Red lentil & Rice \\
\hline $\mathrm{Al}$ & 23.6 & 7.3 & 5.1 & 6.6 & 12.6 & 11.9 & 3.7 & 8.4 \\
\hline B & 0.4 & 0.2 & 0.2 & 0.4 & $\mathrm{ND}^{\mathrm{a}}$ & ND & 0.5 & ND \\
\hline $\mathrm{Ba}$ & 0.9 & 2.1 & 0.3 & 1.6 & 4.8 & $\mathrm{ND}$ & ND & ND \\
\hline $\mathrm{Bi}$ & 0.1 & 0.7 & 0.6 & 0.9 & 1.1 & 0 & 1.1 & 0.9 \\
\hline $\mathrm{Ca}$ & 1766 & 870.9 & 1689 & 475.7 & 4303 & 215.7 & 298.4 & 124.9 \\
\hline $\mathrm{Cd}$ & ND & ND & ND & ND & ND & ND & ND & ND \\
\hline $\mathrm{Co}$ & 1.4 & 0.7 & 1.3 & 0.8 & 1.1 & 0.8 & 0.8 & 0.8 \\
\hline $\mathrm{Cr}$ & 0.9 & 1.8 & 0.1 & 1.2 & 0.9 & 1.0 & 0.1 & 0.2 \\
\hline $\mathrm{Cu}$ & 13.7 & 4.4 & 0.7 & 10.3 & 5.3 & 3.0 & 7.9 & 3.8 \\
\hline $\mathrm{Fe}$ & 179.3 & 52.7 & 44.3 & 76.0 & 107.9 & 158.5 & 51.3 & 40.0 \\
\hline K & 7938 & 3942 & 11950 & 8627 & 9152 & 2662 & 7553 & 778.4 \\
\hline $\mathrm{La}$ & ND & ND & ND & ND & ND & ND & ND & ND \\
\hline $\mathrm{Mg}$ & 1317 & 716.5 & 899.2 & 731.2 & 1479 & 91.5 & 533.9 & 259.7 \\
\hline $\mathrm{Mn}$ & 16.7 & 32.0 & 15.7 & 8.9 & 53.7 & 8.4 & 7.0 & 7.4 \\
\hline $\mathrm{Na}$ & 106.1 & 37.1 & 8.8 & 37.8 & 167.4 & 75.8 & 27.7 & 70.7 \\
\hline $\mathrm{Ni}$ & 1.0 & 3.7 & 3.4 & 1.5 & 0.4 & 0.022 & 1.0 & ND \\
\hline $\mathrm{Pb}$ & 0.2 & 0.3 & 0.1 & 2.2 & 0.6 & 1.5 & 1.1 & 0.5 \\
\hline $\mathrm{Sb}$ & ND & ND & ND & ND & ND & ND & ND & ND \\
\hline $\mathrm{Si}$ & 50.6 & 294.3 & 40.4 & 49.7 & 25.6 & 31.3 & 14.1 & 15.6 \\
\hline $\mathrm{Sn}$ & 3.2 & 2.5 & 2.6 & 3.4 & 1.7 & 2.4 & 1.9 & 0.038 \\
\hline $\mathrm{Sr}$ & 4.6 & 8.5 & 13.2 & 2.0 & 24.8 & 0.9 & 1.0 & 0.6 \\
\hline $\mathrm{Ti}$ & 0.7 & 0.5 & 0.3 & 0.5 & 0.4 & 0.8 & ND & 0.5 \\
\hline $\mathrm{U}$ & ND & 0.8 & 0.8 & 0.6 & 0.4 & ND & 0.3 & 1.0 \\
\hline $\mathrm{Zn}$ & 47.7 & 14.0 & 12.1 & 22.8 & 24.3 & 28.4 & 19.7 & 16.7 \\
\hline $\mathrm{Zr}$ & 0.1 & 0.0064 & 0.1 & 0.1 & 0.1 & 0.1 & 0.1 & 2.0 \\
\hline
\end{tabular}

${ }^{\mathrm{a}} \mathrm{ND}$ : Not Detection.

[17]. In another study in Czechoslavakia, the concentrations of element $\mathrm{Cu}$ and $\mathrm{Zn}$ were measured as $8.52 \mu \mathrm{g} / \mathrm{g}$ and $42.1 \mu \mathrm{g} / \mathrm{g}$, respectively, in the seeds of soya bean, lentil and bean by using ICP-MS [18]. In the element analysis of Vicia faba L. var. major, the concentrations of element $\mathrm{Ca}, \mathrm{P}, \mathrm{K}, \mathrm{Mg}, \mathrm{Na}, \mathrm{S}, \mathrm{Al}, \mathrm{B}, \mathrm{Ba}, \mathrm{Co}, \mathrm{Cr}, \mathrm{Cu}, \mathrm{Fe}$, $\mathrm{Ga}, \mathrm{Li}, \mathrm{Mn}, \mathrm{Ni}, \mathrm{Pb}, \mathrm{Sr}$ and $\mathrm{Zn}$ were measured as 728.6 $\mathrm{mg} / \mathrm{kg}, 6545.46 \mathrm{mg} / \mathrm{kg}, 15486.05 \mathrm{mg} / \mathrm{kg}, 1426.27 \mathrm{mg} / \mathrm{kg}$, $499.70 \mathrm{mg} / \mathrm{kg}, 497459.95 \mathrm{mg} / \mathrm{kg}, 15.46 \mathrm{mg} / \mathrm{kg}, 10.97$ $\mathrm{mg} / \mathrm{kg}, 31.02 \mathrm{mg} / \mathrm{kg}, 0.66 \mathrm{mg} / \mathrm{kg}, 11.25 \mathrm{mg} / \mathrm{kg}, 18.00$ $\mathrm{mg} / \mathrm{kg}, 89.17 \mathrm{mg} / \mathrm{kg}, 0.33 \mathrm{mg} / \mathrm{kg}, 0.067 \mathrm{mg} / \mathrm{kg}, 15.91$ $\mathrm{mg} / \mathrm{kg}, 3.83 \mathrm{mg} / \mathrm{kg}, 1.50 \mathrm{mg} / \mathrm{kg}, 5.25 \mathrm{mg} / \mathrm{kg}$ and 52.83 $\mathrm{mg} / \mathrm{kg}$, respectively, by using ICP-AES [19].

S.D'llio et al. (2002) have done element analysis for 8 different type of rice by using plasma-based techniques (ICP-AES, Q-ICP-MS, HR-ICP-MS) in Italy. Concentrations of $\mathrm{Cd}, \mathrm{Co}, \mathrm{Cr}, \mathrm{Cu}, \mathrm{Fe}, \mathrm{Mn}, \mathrm{Pb}, \mathrm{V}$ and $\mathrm{Zn}$ varied as $15.6-228 \mathrm{ng} / \mathrm{g}, 4.40-30.9 \mathrm{ng} / \mathrm{g}, 2.1-4.7 \mathrm{ng} / \mathrm{g}, 1958-$ $3165 \mathrm{ng} / \mathrm{g}, 2378-5014 \mathrm{ng} / \mathrm{g}, 4656-11847 \mathrm{ng} / \mathrm{g}, 4.57$ $17.3 \mathrm{ng} / \mathrm{g}, 2.48-5.16 \mathrm{ng} / \mathrm{g}$ and $7510-20529 \mathrm{ng} / \mathrm{g}$, re- spectively [20]. Lee et al. made element analysis in soils, plants and waters by using ICP-AES in Korea in 2001. In this study, concentrations of $\mathrm{Cd}, \mathrm{Cu}, \mathrm{Pb}$ and $\mathrm{Zn}$ for rice varied as $0.01-0.24 \mathrm{mg} / \mathrm{kg}, 1.0-3.0 \mathrm{mg} / \mathrm{kg}, 0.2-0.5$ $\mathrm{mg} / \mathrm{kg}$ and $8.4-18.4 \mathrm{mg} / \mathrm{kg}$, respectively [21]. In another study in Korea, Jung et al. made element analysis in soils, plants, waters and sediments by using ICP-AES. The concentrations of element $\mathrm{As}, \mathrm{Sb}$ and $\mathrm{Bi}$ for corn particles varied as $0.03-0.06 \mu \mathrm{g} / \mathrm{g},<0.01 \mu \mathrm{g} / \mathrm{g}$ and $0.01-$ $0.02 \mu \mathrm{g} / \mathrm{g}$, respectively [22].

Statistical evaluations in Tables have been concluded by using ANOVA one way of statistical test. Meaningful values $(\mathrm{P}<0.05$ and $\mathrm{P}<0.01$ levels $)$ have been obtained between the concentrations of element Co determined in the seeds and $\mathrm{Na}, \mathrm{Ca}, \mathrm{Cu}, \mathrm{Mn}, \mathrm{Sn}, \mathrm{Sr}, \mathrm{Si}, \mathrm{Bi}$ and $\mathrm{Zr}$ concentrations by using ANOVA test. It is shown that there is a relation between the concentrations of element $\mathrm{Co}$ and other element concentrations.

Especially, the relation with $\mathrm{Na}$ is forceful $(\mathrm{P}=0.003)$, is seen in Table 2. 
Table 2. Comparison of Co concentration with the other elements.

\begin{tabular}{cccc}
\hline Element & F-ratio & Probability & Significance \\
\hline $\mathrm{Ba}$ & 4.49 & 0.487 & $\mathrm{NS}^{\mathrm{b}}$ \\
$\mathrm{Bi}$ & 4.18 & 0.044 & $*$ \\
$\mathrm{Ca}$ & 6.03 & 0.028 & $*$ \\
$\mathrm{Cr}$ & 0.64 & 0.435 & $\mathrm{NS}$ \\
$\mathrm{Cu}$ & 11.84 & 0.004 & ${ }^{* *}$ \\
$\mathrm{Mn}$ & 9.56 & 0.008 & $* *$ \\
$\mathrm{Na}$ & 13.06 & 0.003 & $* *$ \\
$\mathrm{Ni}$ & 1.00 & 0.335 & $\mathrm{NS}$ \\
$\mathrm{Pb}$ & 0.38 & 0.537 & $\mathrm{NS}$ \\
$\mathrm{Si}$ & 4.33 & 0.040 & $*$ \\
$\mathrm{Sn}$ & 10.70 & 0.006 & $* *$ \\
$\mathrm{Sr}$ & 4.63 & 0.034 & $*$ \\
$\mathrm{Zr}$ & 8.39 & 0.005 & $* *$ \\
\hline
\end{tabular}

${ }^{\mathrm{b}} \mathrm{NS}$ : Not significant; ${ }^{* *} \mathrm{P}<0.01 ;{ }^{*} \mathrm{P}<0.05$.

$\mathrm{Na}$ is the best element which shows forceful relations with the other element concentrations in the seeds. Meaningful values $(\mathrm{P}<0.05$ and $\mathrm{P}<0.01$ levels $)$ have been obtained between the concentration of this element and $\mathrm{Ca}, \mathrm{Al}, \mathrm{B}, \mathrm{Ba}, \mathrm{Cu}, \mathrm{Mn}, \mathrm{Ni}, \mathrm{Zn}, \mathrm{Cr}$ and $\mathrm{Sn}$ concentrations. Significance at $\mathrm{P}<0.05$ level has been obtained between $\mathrm{Ca}$ concentrations and the other element concentrations except $\mathrm{Mg}$.

In Table 3, Al concentrations in the seeds have got a significance with $\mathrm{B}, \mathrm{Ba}, \mathrm{Ni}, \mathrm{Zn}, \mathrm{Cr}$ and $\mathrm{Sn}$ concentrations at $\mathrm{P}<0.01$ level. This indicates that the relation among them is meaningful.

Element $\mathrm{B}$ has got an important correlation with $\mathrm{Cu}$, $\mathrm{Mn}, \mathrm{Bi}$ at $\mathrm{P}<0.01$ significance level, and also with $\mathrm{Cr}$, $\mathrm{Sr}, \mathrm{Si}, \mathrm{Pb}, \mathrm{U}$ at $\mathrm{P}<0.05$ significance level. But, B hasn't a meaningful relation with $\mathrm{Ba}$.

The concentrations of element $\mathrm{Ba}$ have a significant relation with $\mathrm{Cu}, \mathrm{Mn}, \mathrm{U}, \mathrm{Zr}, \mathrm{Sr}, \mathrm{Si}$ and $\mathrm{Bi}$ concentrations (Table 4).

Element $\mathrm{Cu}$ in the seeds only changes with $\mathrm{Ni}, \mathrm{Zn}, \mathrm{Cr}$ and $\mathrm{Sn}$. Changing of the concentration of $\mathrm{Cu}$ also depends on the concentrations of $\mathrm{Co}, \mathrm{Na}, \mathrm{Ca}, \mathrm{B}$, and $\mathrm{Ba}$ (Table 5).

Mn concentrations in the seeds have a correlation with the other element concentrations at $\mathrm{P}<0.01$ significance level. But, Mn isn't have a relation with $\mathrm{Zn}$ and $\mathrm{Si}$.

$\mathrm{Ni}$ concentrations have a meaningful relation with only $\mathrm{Na}, \mathrm{Ca}, \mathrm{Al}, \mathrm{Cu}$ and $\mathrm{Mn}$ concentrations (Tables 3, 5). Then, it can be said that Ni concentrations show variation dependently with those element concentrations.

The concentrations of element $\mathrm{Zn}$ only change with concentrations of element $\mathrm{Al}, \mathrm{Cu}$, and $\mathrm{Na}, \mathrm{Ca}, \mathrm{Fe}, \mathrm{Sr}$ (Tables 3, 5 and 6).
Table 3. Comparison of Al concentration with the other elements.

\begin{tabular}{cccc}
\hline Element & F-ratio & Probability & Significance \\
\hline $\mathrm{B}$ & 18.73 & 0.001 & $* *$ \\
$\mathrm{Ba}$ & 14.11 & 0.002 & $* *$ \\
$\mathrm{Cr}$ & 16.48 & 0.001 & $* *$ \\
$\mathrm{Cu}$ & 1.95 & 0.184 & $\mathrm{NS}$ \\
$\mathrm{Ni}$ & 13.48 & 0.003 & $* *$ \\
$\mathrm{Si}$ & 3.240 & 0.075 & $\mathrm{NS}$ \\
$\mathrm{Sn}$ & 11.047 & 0.004 & $* *$ \\
$\mathrm{Sr}$ & 1.060 & 0.305 & $\mathrm{NS}$ \\
$\mathrm{Zn}$ & 8.47 & 0.011 & $* *$ \\
\hline
\end{tabular}

${ }^{\mathrm{b}} \mathrm{NS}$ : Not significant; ${ }^{* *} \mathrm{P}<0.01 ;{ }^{*} \mathrm{P}<0.05$.

Table 4. Comparison of Ba concentration with the other elements.

\begin{tabular}{cccc}
\hline Element & F-ratio & Probability & Significance \\
\hline $\mathrm{Bi}$ & 6.35 & 0.013 & ${ }^{*}$ \\
$\mathrm{Cr}$ & 0.49 & 0.494 & $\mathrm{NS}$ \\
$\mathrm{Cu}$ & 9.34 & 0.009 & ${ }^{* *}$ \\
$\mathrm{Mn}$ & 9.20 & 0.009 & ${ }^{* *}$ \\
$\mathrm{Ni}$ & 0.12 & 0.737 & $\mathrm{NS}$ \\
$\mathrm{Pb}$ & 1.86 & 0.176 & $\mathrm{NS}$ \\
$\mathrm{Si}$ & 4.30 & 0.041 & ${ }^{*}$ \\
$\mathrm{Sn}$ & 2.10 & 0.169 & $\mathrm{NS}$ \\
$\mathrm{Sr}$ & 4.23 & 0.042 & ${ }^{*}$ \\
$\mathrm{U}$ & 12.35 & 0.001 & ${ }^{* *}$ \\
$\mathrm{Zr}$ & 10.62 & 0.002 & ${ }^{* *}$ \\
\hline
\end{tabular}

${ }^{\mathrm{b}} \mathrm{NS}$ : Not significant; ${ }^{* *} \mathrm{P}<0.01 ;{ }^{*} \mathrm{P}<0.05$.

Table 5. Comparison of $\mathrm{Cu}$ concentration with the other elements.

\begin{tabular}{cccc}
\hline Element & F-ratio & Probability & Significance \\
\hline $\mathrm{Cr}$ & 12.51 & 0.003 & ${ }^{* *}$ \\
$\mathrm{Mn}$ & 4.52 & 0.052 & $\mathrm{NS}$ \\
$\mathrm{Ni}$ & 8.65 & 0.011 & ${ }^{* *}$ \\
$\mathrm{Si}$ & 3.68 & 0.058 & $\mathrm{NS}$ \\
$\mathrm{Sn}$ & 6.42 & 0.024 & $*$ \\
$\mathrm{Sr}$ & 0.08 & 0.772 & $\mathrm{NS}$ \\
$\mathrm{Zn}$ & 16.05 & 0.001 & $* *$ \\
\hline
\end{tabular}

${ }^{\mathrm{b}} \mathrm{NS}$ : Not significant; ${ }^{* *} \mathrm{P}<0.01 ;{ }^{*} \mathrm{P}<0.05$.

Table 6. Comparison of $\mathrm{Zn}$ concentration with the other elements.

\begin{tabular}{cccc}
\hline Element & F-ratio & Probability & Significance \\
\hline $\mathrm{Ca}$ & 5.81 & 0.030 & $*$ \\
$\mathrm{Fe}$ & 11.17 & 0.005 & $* *$ \\
$\mathrm{Na}$ & 5.43 & 0.035 & $*$ \\
$\mathrm{Si}$ & 1.59 & 0.228 & $\mathrm{NS}$ \\
$\mathrm{Sr}$ & 10.63 & 0.006 & ${ }^{* *}$ \\
\hline
\end{tabular}

${ }^{\mathrm{b}} \mathrm{NS}$ : Not significant; ${ }^{* *} \mathrm{P}<0.01 ;{ }^{*} \mathrm{P}<0.05$. 
Element $\mathrm{Cr}$ has a meaningful relation only with $\mathrm{Sn}$ at $\mathrm{P}<0.01$ significance level.

Element $\mathrm{Sn}$ has a meaningful relation with $\mathrm{Bi}, \mathrm{U}$ and $\mathrm{Zr}$ at $\mathrm{P}<0.01$ level (Table 7). Sn is also an element which is of little amount in the seeds (Table 1).

$\mathrm{Ti}$, an element which is of quite little amount in the seeds has a relation with only $\mathrm{Sr}$ and $\mathrm{Si}$ at $\mathrm{P}<0.05$ level.

$\mathrm{Fe}$ concentrations analyzed in the plant seeds were compared with some other element results by using ANOVA test. Element $\mathrm{Fe}$ has a meaningful relation with only $\mathrm{Mn}, \mathrm{Zn}$ and $\mathrm{Sr}$ at $\mathrm{P}<0.01$ significance levels (Table 8).

Element $\mathrm{Sr}$ is not have a meaningful relation with the other elements except $\mathrm{Co}, \mathrm{B}, \mathrm{Ba}, \mathrm{Zn}, \mathrm{Ti}$ and $\mathrm{Fe}, \mathrm{U}, \mathrm{Zr}$, (Tables 2, 4, 7).

According to Table 9, element $\mathrm{Si}$ is not have a meaningful relation with the other elements except $\mathrm{Co}, \mathrm{B}, \mathrm{Ba}$ and Ti (Tables 2, 4).

Element $\mathrm{Pb}$ is not have a meaningful relation with the other elements except Mn and B. Merian (1991) pointed out that the lead concentrations are highest in the roots,

Table 7. Comparison of Sn concentration with the other elements.

\begin{tabular}{cccc}
\hline Element & F-ratio & Probability & Significance \\
\hline $\mathrm{Bi}$ & 14.80 & 0.002 & $* *$ \\
$\mathrm{Si}$ & 3.62 & 0.078 & $\mathrm{NS}$ \\
$\mathrm{Sr}$ & 2.46 & 0.139 & $\mathrm{NS}$ \\
$\mathrm{U}$ & 19.19 & 0.001 & $* *$ \\
$\mathrm{Zr}$ & 18.29 & 0.001 & $*$ \\
\hline
\end{tabular}

${ }^{\mathrm{b}} \mathrm{NS}$ : Not significant; ${ }^{* *} \mathrm{P}<0.01 ;{ }^{*} \mathrm{P}<0.05$.

Table 8. Comparison of Fe concentration with the other elements.

\begin{tabular}{cccc}
\hline Element & F-ratio & Probability & Significance \\
\hline $\mathrm{Mn}$ & 12.17 & 0.004 & $* *$ \\
$\mathrm{Na}$ & 1.39 & 0.241 & $\mathrm{NS}$ \\
$\mathrm{Si}$ & 0.38 & 0.548 & $\mathrm{NS}$ \\
$\mathrm{Sr}$ & 17.72 & 0.001 & $* *$ \\
$\mathrm{Zn}$ & 11.17 & 0.005 & $* *$ \\
\hline
\end{tabular}

${ }^{\mathrm{b}} \mathrm{NS}$ : Not significant; ${ }^{* *} \mathrm{P}<0.01 ;{ }^{*} \mathrm{P}<0.05$.

Table 9. Comparison of Si concentration with the other elements.

\begin{tabular}{cccc}
\hline Element & F-ratio & Probability & Significance \\
\hline $\mathrm{Bi}$ & 3.80 & 0.072 & $\mathrm{NS}$ \\
$\mathrm{Pb}$ & 3.78 & 0.072 & $\mathrm{NS}$ \\
$\mathrm{U}$ & 3.82 & 0.071 & $\mathrm{NS}$ \\
$\mathrm{Zr}$ & 3.84 & 0.070 & $\mathrm{NS}$ \\
\hline
\end{tabular}

${ }^{\mathrm{b}} \mathrm{NS}$ : Not significant; ${ }^{* *} \mathrm{P}<0.01 ;{ }^{*} \mathrm{P}<0.05$. lower in stems and leaves, and lowest in flowers or seeds [15].

Element $\mathrm{Bi}$ is not have a relation with the other elements except $\mathrm{Co}, \mathrm{B}, \mathrm{Ba}$, and $\mathrm{Mn}, \mathrm{Sn}$.

\section{CONCLUSIONS}

Some of the trace elements including iron, manganese, zinc and copper are essential micronutrients with a variety of biochemical functions in all living organisms. The concentrations of element $\mathrm{Mn}, \mathrm{Fe}, \mathrm{Zn}$ and $\mathrm{Cu}$ were measured as $16.7 \mathrm{mg} / \mathrm{kg}, 179.3 \mathrm{mg} / \mathrm{kg}, 47.7 \mathrm{mg} / \mathrm{kg}$ and $13.7 \mathrm{mg} / \mathrm{kg}$ in clover; $32.0 \mathrm{mg} / \mathrm{kg}, 52.7 \mathrm{mg} / \mathrm{kg}, 14.0$ $\mathrm{mg} / \mathrm{kg}$ and $4.4 \mathrm{mg} / \mathrm{kg}$ in oats; $15.7 \mathrm{mg} / \mathrm{kg}, 44.3 \mathrm{mg} / \mathrm{kg}$, $12.1 \mathrm{mg} / \mathrm{kg}$ and $0.7 \mathrm{mg} / \mathrm{kg}$ in bean; $8.9 \mathrm{mg} / \mathrm{kg}, 76.0$ $\mathrm{mg} / \mathrm{kg}, 22.8 \mathrm{mg} / \mathrm{kg}$ and $10.3 \mathrm{mg} / \mathrm{kg}$ in green lental; 53.7 $\mathrm{mg} / \mathrm{kg}, 107.9 \mathrm{mg} / \mathrm{kg}, 24.3 \mathrm{mg} / \mathrm{kg}$ and $5.3 \mathrm{mg} / \mathrm{kg}$ in spinach; $8.4 \mathrm{mg} / \mathrm{kg}, 158.5 \mathrm{mg} / \mathrm{kg}, 28.4 \mathrm{mg} / \mathrm{kg}$ and $3.0 \mathrm{mg} / \mathrm{kg}$ in corn; $7.0 \mathrm{mg} / \mathrm{kg}, 51.3 \mathrm{mg} / \mathrm{kg}, 19.7 \mathrm{mg} / \mathrm{kg}$ and 7.9 $\mathrm{mg} / \mathrm{kg}$ in red lental; $7.4 \mathrm{mg} / \mathrm{kg}, 40.0 \mathrm{mg} / \mathrm{kg}, 16.7 \mathrm{mg} / \mathrm{kg}$ and $3.8 \mathrm{mg} / \mathrm{kg}$ in rice, respectively by using ICP-OES.

In present study, it seems that many elements in the seeds have meaningful relations among them at $\mathrm{P}<0.05$ and $\mathrm{P}<0.01$ significance levels. The forceful relation ( $\mathrm{P}$ $\leq 0.003$ ) between elements is found as follows: Co with $\mathrm{Na}$; $\mathrm{Al}$ with $\mathrm{B}, \mathrm{Ba}, \mathrm{Ni}$ and $\mathrm{Cr}$; $\mathrm{Ba}$ with $\mathrm{U}$ and $\mathrm{Zr}$; $\mathrm{Cu}$ with $\mathrm{Zn}$ and $\mathrm{Cr}$; Fe with $\mathrm{Sr}$.

But element $\mathrm{Mg}$ in the seeds is not have any statistical relation with the other elements. According to this result, it can be said that $\mathrm{Mg}$ concentration indicates variation independently from the other element concentrations. Element $\mathrm{K}$ which is of many amount in the seeds is also independent from the other elements.

\section{REFERENCES}

[1] Rodriguez, L.H., Morales, D.A., Rodriguez, E.R. and Romero, C.D. (2011) Minerals and trace elements in a collection of wheat landraces from the Canary Islands. Journal of Food Composition and Analysis, 24, 10811090. doi:10.1016/j.jfca.2011.04.016

[2] Korkmaz, K., Kara, S.M., Ozkutlu, F. and Gul, V. (2010) Monitoring of heavy metals and selected micronutrients in hempseeds from north-western Turkey. African Journal of Agricultural Research, 5, 463-467.

[3] Anke, M., Seeber, O., Müller, R., Schäfer, U. and Zerull, J. (2009) Uranium transfer in the food chain from soil to plants, animals and man. Chemie der Erde, 69, 75-90. doi:10.1016/i.chemer.2007.12.001

[4] Ajayi, I.A. (2008) Comparative study of the chemical composition and mineral element content of Artocarpus heterophyllus and Treculia africana seeds and seed oils. Bioresource Technology, 99, 5125-5129. doi:10.1016/j.biortech.2007.09.027

[5] Naozuka, J., Marana, S.R. and Oliveira, P.V. (2010) Water-soluble $\mathrm{Cu}, \mathrm{Fe}, \mathrm{Mn}$ and $\mathrm{Zn}$ species in nuts and seeds. 
Journal of Food Composition and Analysis, 23, 78-85. doi:10.1016/j.jfca.2009.08.003

[6] Rodushkina, I., Engström, E., Sörlinb, D. and Baxter, D. (2008) Levels of inorganic constituents in raw nuts and seeds on the Swedish market. Science of the Total Environment, 392, 290-304.

doi:10.1016/j.scitotenv.2007.11.024

[7] Adelakun, O.E., Oyelade, O.J., Ade-Omowaye, B.I.O., Adeyemi, I.A. and Venter, M.V. (2009) Chemical composition and the antioxidative properties of Nigerian Okra seed (Abelmoschus esculentus Moench) flour. Food and Chemical Toxicology, 47, 1123-1126. doi:10.1016/i.fct.2009.01.036

[8] Bakoglu, A., Bagci, E. and Ciftci, H. (2009) Fatty acids, protein contents and metal composition of some feed crops from Turkey. Journal of Food Agriculture \& Environment, 7, 343-346.

[9] Kranner, I. and Colville, L. (2011) Metals and seeds: Biochemical and molecular implications and their significance for seed germination. Environmental and Experimental Botany, 72, 93-105. doi:10.1016/j.envexpbot.2010.05.005

[10] Sardans, J., Montes, F. and Peñuelas, J. (2010) Determination of $\mathrm{As}, \mathrm{Cd}, \mathrm{Cu}, \mathrm{Hg}$ and $\mathrm{Pb}$ in biological samples by modern electrothermal atomic absorption spectrometry. Spectrochimica Acta Part B, 65, 97-112. doi:10.1016/j.sab.2009.11.009

[11] Chaves, E.S., Santos, E.J., Araujo, R.G.O., Oliveira, J.V., Frescura, V.L.A. and Curtius, A.J. (2010) Metals and phosphorus determination in vegetable seeds used in the production of biodiesel by ICP OES and ICP-MS. Microchemical Journal, 96, 71-76. doi:10.1016/j.microc.2010.01.021

[12] Jung, M.C. and Thornton, I. (1997) Environmental contamination and seasonal variation of metal in soils, plants and waters in the paddy fields around $\mathrm{a} \mathrm{Pb}-\mathrm{Zn}$ mine in Korea. The Science of the Total Environment, 198, 105121. doi:10.1016/S0048-9697(97)05434-X

[13] Schaefer, R.L. and Anderson, R.B. (1989) The student edition of minitab and Microsta, user's manuel. Addison Wesley Publishing Company Inc., New York.
[14] Takahashi, M., Nozoye, T., Kitajima, N., Fukuda, N. and Hokura, A. (2009) In vivo analysis of metal distribution and expression of metal transporters in rice seed during germination process by microarray and X-ray fluorescence imaging of $\mathrm{Fe}, \mathrm{Zn}, \mathrm{Mn}$, and $\mathrm{Cu}$. Plant and Soil, 325, 39-51. doi:10.1007/s11104-009-0045-7

[15] Merian, E. (1991) Metals and their compouns in the environment. VCH Pub, New York.

[16] Mohamed, A.E., Rashed, M.N. and Mofty, A. (2003) Assessment of essential and toxic elements in some kinds of vegetables. Ecotoxicology and Environmental Safety, 55, 251-260. doi:10.1016/S0147-6513(03)00026-5

[17] Koplik, R., Borkova, M., Mestek, O., Kominkova, J. and Suchanek, M. (2002) Application of size exclusion chromatography-inductively coupled plasma mass spectrometry for fractionation of element species in seeds of legumes. Journal of Chromatography B, 775, 179-187. doi:10.1016/S1570-0232(02)00296-9

[18] Mestek, O., Kominkova, J., Koplik, R., Borkova, M. and Suchanek, M. (2002) Quantification of copper and zinc species fractions in legume seeds extracts by SEC/ICPMS: Validation and uncertainty estimation. Talanta, 57, 1133-1142. doi:10.1016/S0039-9140(02)00151-0

[19] Hacıseferoğulları, H., Gezer, I., Bahtiyarca, Y. and Mengeş, H.O. (2003) Determination of some chemical and physical properties of Sakı faba bean (Vicia faba L. var. major). Journal of Food Engineering, 60, 475-479.

[20] D'llio, S., Alessandrelli, M., Cresti, R., Forte, G. and Caroli, S. (2002) Arsenic content of various types of rice as determined by plasma-based techniques. Microchemical Journal, 73, 195-201. doi:10.1016/S0026-265X(02)00064-4

[21] Lee, C.G., Chon, H.T. and Jung, M.C. (2001) Heavy metal contamination in the vicinity of the Daduk Au-Ag$\mathrm{Pb}-\mathrm{Zn}$ mine in Korea. Applied Geochemistry, 16, 13771386. doi:10.1016/S0883-2927(01)00038-5

[22] Jung, M.C., Thornton, I. and Chon, H. (2002) Arsenic, Sb and $\mathrm{Bi}$ contamination of soils, plants, waters and sediments in the vicinity of the Dalsung $\mathrm{Cu}-\mathrm{W}$ mine in Korea. The Science of the Total Environment, 295, 81-89. doi:10.1016/S0048-9697(02)00042-6 